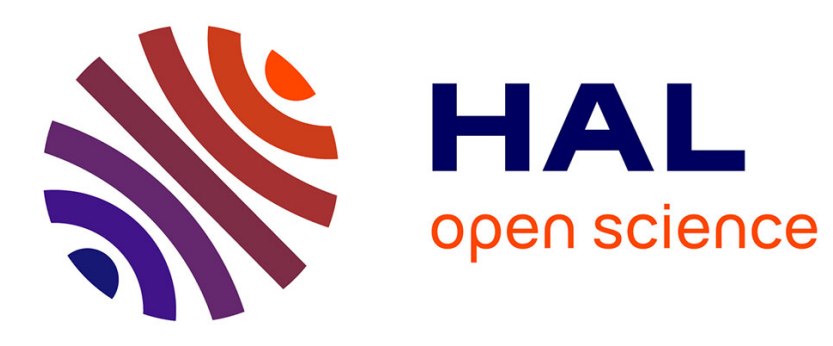

\title{
The French GAZEL Cohort Study: 20 years of epidemiologic research
}

\author{
Marie Zins, Annette Leclerc, Marcel Goldberg
}

\section{To cite this version:}

Marie Zins, Annette Leclerc, Marcel Goldberg. The French GAZEL Cohort Study: 20 years of epidemiologic research. Advances in Life Course Research, 2009, 14 (4), pp.135-146. 10.1016/j.alcr.2010.02.003 . inserm-00488925

\section{HAL Id: inserm-00488925 https://www.hal.inserm.fr/inserm-00488925}

Submitted on 3 Jun 2010

HAL is a multi-disciplinary open access archive for the deposit and dissemination of scientific research documents, whether they are published or not. The documents may come from teaching and research institutions in France or abroad, or from public or private research centers.
L'archive ouverte pluridisciplinaire HAL, est destinée au dépôt et à la diffusion de documents scientifiques de niveau recherche, publiés ou non, émanant des établissements d'enseignement et de recherche français ou étrangers, des laboratoires publics ou privés. 
Title: The French GAZEL Cohort Study: 20 years of epidemiologic research

Authors: Marie Zins ${ }^{1,2}$, Annette Leclerc ${ }^{1,2}$, Marcel Goldberg ${ }^{1,2}$

Affiliation:

1. Inserm U1018, Epidemiology of Social and Occupational Determinants of Health, CESP

Centre for research in Epidemiology and Population Health, 16 avenue Paul Vaillant-

Couturier, F-94807, Villejuif, France

2. Université de Versailles St-Quentin, France

E-mails:

marie.zins@inserm.fr

annette.leclerc@inserm.fr

marcel.goldberg@inserm.fr

Corresponding author:

Marcel Goldberg

通 +33177747400

\$33177747403 


\section{ABSTRACT}

The GAZEL Cohort Study was set up in 1989 among Électricité de France-Gaz de France (EDF-GDF) workers. It is an open epidemiologic laboratory characterized by a broad coverage of health problems and determinants and accessible to the community of researchers. At inception in 1989, the GAZEL Cohort Study included 20625 volunteers working at EDF-GDF then aged from 35 to 50 years (15 011 men and 5614 women). The cohort is broadly diverse in terms of social, economic, and occupational status, health, and health-related behavior. The data collected routinely cover diverse dimensions and come from different sources: annual self-administered questionnaire (morbidity, lifestyles, life events, etc.); personnel department of EDF-GDF for social, demographic, and occupational characteristics; EDF-GDF special social insurance fund (for sickness absences and cancer and ischemic heart disease registries), occupational medicine (occupational exposure and working conditions), Social Action Fund (healthcare utilization), Health Screening Centers for standardized health examination and the constitution of a biobank, and the National Death Register (causes of death). Follow-up has been excellent, and the number of subjects lost to follow-up was exceptionally low; active participation by the self-administered questionnaire is also elevated.

Today, more than 40 projects on diversified themes have been set up in the GAZEL Cohort Study by some 30 French and foreign teams. Different health problems taking into account behavioral, social, psychological and medical occupational risk factors have been the object of research projects in the cohort. A substantial proportion of the research work has focused on social inequalities in health. Here, we present a brief panorama of the main fields covered by research in the GAZEL Cohort Study that have already been published over the years. 


\section{KEY WORDS}

Epidemiology, Cohort study, Follow-up, Open Epidemiologic Laboratory 


\section{THE CONTRIBUTION OF EPIDEMIOLOGIC COHORTS TO KNOWLEDGE}

\section{ABOUT HEALTH}

Epidemiology is the scientific discipline that studies the health of populations. Only by epidemiologic methods can we determine the frequency of health problems, their distribution according to diverse criteria (age, sex, occupational and social status, region, etc.), and their course over time. Epidemiology also allows to understand the determinants of health status and of diseases: it is the science that showed the role in numerous health problems of what are now known risk factors - physical and chemical factors such as smoking or asbestos, as well as psychological or socioeconomic factors. Finally epidemiology makes it possible to assess the efficacy of health activities — screening, prevention, and health care utilization.

Epidemiology permits a comprehensive approach to health, in all its dimensions, both individual and collective. It is therefore an essential tool for determining health policies, planning health prevention, and assessing health actions.

Epidemiology uses different methods; among these, diverse characteristics make cohorts a tool of choice. An epidemiologic cohort is a type of survey based on the principle of longitudinal follow-up of a group of subjects on an individual scale. From the methodological point of view, the principal advantage of cohorts is that they optimize the consideration of different factors related to living conditions (e.g., diet, housing, access to care, and social network), the environmental situation (occupational and environmental exposure), and health status (chronology of phenomena). Globally, cohort studies provide the best conditions for judging the role that risk factors or preventive interventions play in health, by allowing consideration of changes over time and of interactions between factors. 
The prospective character of cohorts makes it possible to plan data collection about exposures to numerous risk factors and preventive activities and to take into account very diverse health problems, assessed in terms of morbidity or even preclinical conditions, and of mortality.

The domains of cohort use are as diverse as epidemiology itself and concern all aspects of health related to risk factors of different types.

\section{THE GAZEL COHORT STUDY}

\section{AN OPEN EPIDEMIOLOGIC LABORATORY}

The GAZEL Cohort Study was set up in 1989 by Inserm Unit 88 (subsequently Unit 687), in cooperation with several departments of Électricité de France-Gaz de France (EDF-GDF), at that time a public utility firm in France involved in the production, transmission and distribution of energy. For several reasons, EDF-GDF is a unique setting for epidemiology. The company (now split in several companies) employs about 150000 workers in all regions of France, from large cities to small villages; there is a wide socioeconomic range of occupational positions, including white- and blue-collar workers. The workforce is very stable due to their civil servant-like status, employees almost never leave the company and are not lost to follow-up even after retirement, since retirement benefits are paid by the company itself. An extensive human resources system allows for a complete follow-up of workers, even when they retire. EDF-GDF has its own Occupational Health and Social Insurance system; about 300 physicians work for the company and are responsible for the health surveillance of the workers.

The GAZEL Cohort Study is an open epidemiologic laboratory. Like major scientific instruments (telescopes or particle accelerators, for example, or genotyping laboratories equipped with sequencers), GAZEL was not constructed to answer a specific question. Instead it was designed to help analyze a wide range of scientific problems and is accessible 
to the community of researchers specializing in epidemiology. It is for this reason that it is characterized by a broad coverage of health problems and determinants and openness towards diverse users. Its duration is not defined: the cohort is intended to serve as an object of longitudinal follow-up without any time limit, to be able simultaneously to study the effects of risk factors over a very long term and to take into account progress in knowledge and techniques, progress that continuously raises new scientific questions that the GAZEL Cohort Study can help to illuminate.

\section{THE COMPOSITION OF THE GAZEL COHORT}

A more detailed presentation of the GAZEL Cohort Study is available elsewhere (Goldberg et al, 2007), and we only summarize here its main features. Set up in 1989, the GAZEL Cohort Study initially included 20625 volunteers working at EDF-GDF (15 011 men and 5614 women), then aged from 35 to 50 years. They will be followed up prospectively through death ().

Table 1 presents the cohort's principal characteristics at inclusion: we see that it was broadly diverse in terms of social, economic, and occupational status, health, and health-related behavior. This diversity makes it possible to study numerous epidemiologic problems.

\section{$<$ INSERT TABLE 1 ABOUT HERE $>$}

\section{METHODS}

Inclusion took place in 1989 on a voluntary basis: after an information campaign by EDFGDF management, company health services, union organizations, and the employee social fund (CCAS), workers received a letter and self-administered questionnaire at home. The initial participation rate $(44.7 \%)$ was especially high for a long-term project in France.

The data collected routinely for the entire cohort cover diverse dimensions and come from different sources (Table 2): annual self-administered questionnaire (morbidity, lifestyles, life 
events, etc.); personnel department of EDF-GDF (“GPSO” database for computerized personnel files) for social, demographic, and occupational characteristics; EDF-GDF"SGMC" special social insurance fund (for sickness absences and cancer and ischemic heart disease registries), occupational medicine (occupational exposure and working conditions), Complementary Mutual and Social Action Funds (CMCAS, healthcare utilization), the Health Screening Centers (CES) of the social insurance fund (standardized health examination and biobank), and CepiDc Inserm (causes of death).

\section{$<$ INSERT TABLE 2 ABOUT HERE $>$}

Follow-up has been excellent: at the end of 2008 (after 20 years of follow-up), the number of subjects lost to follow-up was exceptionally low -107 , or approximately $0.5 \%$; active participation by the self-administered questionnaire is particularly elevated (Figure 1), and only $3.1 \%$ of subjects have never returned an annual questionnaire.

\section{<INSERT FIGURE 1 ABOUT HERE >}

These results are due to the interest of the cohort's volunteers in medical research, as well as the major efforts at developing continuous participation (cohort newsletter sent twice a year to participants, media coverage in the popular press of the principal results, annual scientific meeting, website, etc.).

At the end of 2008, there had been 1,314 deaths (1,114 in men; 200 among women); the distribution of the principal causes of death was close to that observed in France for the same age groups (Table 3).

<INSERT TABLE 3 ABOUT HERE> 


\section{GAZEL COHORT STUDY PARTICULARITIES}

Constructed as an "epidemiologic laboratory" intended to serve as a research platform, the design and operation of the GAZEL Cohort Study include some original characteristics to facilitate the performance of diversified epidemiologic research. Below we describe its principal features.

Large size: More than 15000 men and 5000 women comprise the cohort, allowing the study of a wide variety of almost all but the rarest health problems and risk factors.

Diversified population: EDF and GDF are companies that employ workers of very diverse occupations and social categories; the companies cover the entire country and the cohort members live in all the regions of France, in urban and rural areas.

Data diversity and quality: The data collected regularly for all participants come from numerous sources inside and outside the company. They concern very diverse aspects of health (including a biobank where serum samples and DNA are stored), behavior, and lifestyle, occupational, social, and residential environment, and personal, family, occupational, and environmental risk factors. Moreover, they have mostly been collected prospectively and repeatedly for the entire duration of the cohort follow-up.

Annual questionnaire: One unique feature of the GAZEL Cohort Study is its use, from the very beginning, of an annual mail questionnaire. Despite the cumbersome nature of this procedure, it has multiple advantages: long series for some data, allowing the study of changes over time (for example, we have year-to-year trends over two decades in alcohol consumption, smoking, and body weight); the possibility of rapidly including questions on emerging scientific themes or updating data of particular interest; increased loyalty by the cohort members, through their frequent and regular participation. 
Quality of follow-up: Because of the particular status of EDF-GDF employees, the number lost to follow-up is tiny, and we observe strong active participation by the volunteers, expressed especially by a response rate to the questionnaire of around $75 \%$ each year.

Long duration of follow-up: The follow-up has now reached 20 years and should continue without any defined duration; at inception, the volunteers were adults aged 35 to 50 years: the prospectively collected data concerns therefore a large part of their life.

Openness to the research community: Any group, French or foreign, regardless of its affiliation, can propose a research project and thus use the data that has been collected and have access to the volunteers for the collection of complementary data, when appropriate. A standardized procedure, based on the "Regulation of the GAZEL Cohort Study," is intended to specify the modalities of access to the data, to detail the required confidentiality, and to deal with potential scientific conflicts of interests between researchers. 


\section{EPIDEMIOLOGIC RESEARCH IN THE GAZEL COHORT STUDY}

In accordance with its purpose as a scientific research platform, the GAZEL Cohort Study is permanently open to epidemiologic research teams. Today, more than 40 projects on diversified themes have been set up in the GAZEL Cohort Study by some 30 teams — French and foreign (Germany, Belgium, Canada, Great Britain, Sweden, Finland, and USA). Numerous scientific publications in the best epidemiologic and medical specialty journals have reported work conducted in the GAZEL Cohort Study, and their number continues to grow with the duration of follow-up and the development of new research projects, as shown by Figure 2.

\section{<INSERT FIGURE 2 ABOUT HERE>}

\section{RESEARCH THEMES DEVELOPED IN THE GAZEL COHORT STUDY}

Health problems as different as migraine, postmenopausal osteoporosis, ischemic heart disease, depression, musculoskeletal diseases, and traffic accidents have been the object of research projects in the cohort. They take into account risk factors that are behavioral (for example, alcohol, smoking, and nutrition), social (social support, family and professional support for patients with chronic diseases), psychological, occupational (organization of work, psychosocial and biomechanical factors at work), and medical (consumption of medication and treatments). A substantial proportion of the research work has focused on the problem of social inequalities in health and their occupational, personal, and social determinants.

It is not possible to describe in detail all the research findings that have already been published, and we present here only a brief panorama of the main research fields covered in the GAZEL Cohort Study over the years. 


\section{SOCIAL INEQUALITIES IN HEALTH}

Since the establishment of the cohort in 1989, the successive collection of data from different sources has made possible a rich and detailed documentation of the participants' social situation, their living conditions, and their changes over time.

Different studies have described social inequalities and the factors associated with them for different aspects of health. A study of the association between social status in childhood through adulthood and the risk of premature mortality showed that among men, those who worked as office or manual workers throughout their careers were approximately twice as likely to die prematurely as those who had always worked as managers. Given that premature death did not vary according to paternal occupation, social trajectory during adult life appears to be more strongly associated with premature mortality than living conditions during childhood (Melchior et al, 2006). The men who were office or manual workers for their entire career were also twice as likely as career-long managers to have cancer, particularly smokingrelated cancers (Melchior et al, 2005). Office and manual workers had a rate of sickness leave almost three times higher than managers, and almost $20 \%$ of these disparities were explained by occupational factors, including the organization of work, physical constraints such as awkward postures, and other work-related risks (Melchior et al, 2005). A study of the association between contextual socioeconomic characteristics and coronary heart disease (CHD) incidence showed that the classical risk factors (diabetes, hypertension, cholesterol, overweight, tobacco consumption) mediated only a modest part of the association between socioeconomic environmental variables and CHD (Silhol et al 2009). A comparative study of health inequalities between the Whitehall II cohort of British civil servants and the GAZEL Cohort Study showed that the scale of the social gradients was similar in both countries, for health assessed by sickness absences or by self-reported health; on the other hand, health behaviors could differ substantially. For example, fruit and vegetable consumption had a strong social gradient in the Whitehall II study, but none at all in the GAZEL Cohort Study (Fuhrer et al, 2002). Accordingly, it appears that although social inequalities in health exist universally, the ways in which they are expressed vary according to the setting. 
Other research has looked at social determinants of health. Accordingly, we showed that social inequalities for mortality are strongly associated with the psychological profile of the men in this cohort, especially for cardiovascular disease (Nabi et al, 2008), that participation in social activities after retirement is protective against depressive mood disorders (Wahrendorf et al, 2008), that social relations influence self-reported health status (Melchior et al, 2003), that men's diets are largely determined by their wives' social category (Ribet et al, 2001), and that the association between self-reported health and mortality differs according to social position (Singh-Manoux et al, 2007).

\section{WORK AND HEALTH}

The principal aspects of the relation between work and health studied in GAZEL were exposure to psychosocial factors, neuropsychiatric disease, and musculoskeletal disorders.

The role of psychosocial exposure, whether it involves the demands of work, or job latitude, support from superiors and colleagues, balance between the efforts required and the rewards, has been the subject of numerous studies across the world in the past 20 years. The seminal articles in this field of research were published in Sweden in 1989, as the GAZEL Cohort Study was born. The GAZEL Cohort Study has therefore accompanied the development of this research field, especially in the French-speaking world, since the 1990s. It participated in validating the measurement instruments (Niedhammer et al, 2000; Niedhammer, 2002; Siegrist et al, 2004) as well as these health effects: general self-rated health, circulatory and cardiovascular diseases (Niedhammer, 1998a), general mortality (Niedhammer, 2004), mental health (Niedhammer, 1998b), low back pain (Plouvier 2009), and the consequences of health problems, especially work absences for health reasons (Niedhammer, 1998C).

Other topics included mental health problems and disorders of cognitive functioning. A study of the role of occupational and non-occupational factors in depressive and anxiety disorders 
showed that simultaneous exposure to high levels of demand at work and from the family strongly increased the risk of sickness absence for psychiatric disease, especially among women (Melchior et al, 2007). Another study showed that past exposure to solvents plays a negative role in cognitive function (Berr et al, 2005).

The work on low back pain and periarticular disorders showed that having to bend over repeatedly and low support from colleagues and from superiors all increased the risk of low back pain and, still more, the risk of sickness absence (Tubach et al, 2002). Driving a motor vehicle more than two hours a day doubled the risk of sciatica; personal factors also played a role: in particular, being tall increased the risk of sciatica (Leclerc et al, 2003) and the risk of surgery for back problems (Coeuret-Pellicier et al, 2009). The subjects with sciatica most likely to be "cured" were those not exposed to occupational constraints (Tubach et al, 2004). Biomechanical exposures at work had long-term effects on the risk of low back pain. Accordingly, the risk of severe low back pain in 2001 (more than 30 days during the previous 12 months) was doubled for those with exposure for 20 years or more to awkward positions, even though exposure stopped because of retirement (Plouvier et al, 2008). The prevalence of severe low-back pain adjusted for age was significantly higher for blue-collar workers and clerks than for managers. Physical factors accounted for the greatest portion of the observed disparities, even when the role of psychosocial factors was also taken into account. (Plouvier et al, 2009).

Knee pain in 2006 among the men in the ARPEGE Study in a subsample of the cohort was analyzed as a function of occupational constraints reported in 1994-95: 13\% reported knee pain, and the frequency was highest for those who had to work on their knees or in crouching positions and for those who were overweight. Globally, the results show that occupational constraints have long-term effects, beyond retirement (D'Escatha et al, Unpublished results). 
Recent work on retirement in the GAZEL Cohort Study shows that it has been accompanied by an improvement in some aspects of health, including sleep disorders (Vahtera et al, 2009) and perceived health status (Westerlund et al, 2009), and in some risk behaviors, including speeding and telephoning while driving (Bhatti et al, 2008). It strongly suggests that these improvements are largely attributable to the cessation of exposure to diverse occupational risk factors.

\section{WOMEN AND THEIR HEALTH}

The work developed in the GAZEL Cohort Study on the health practices of women around the age of 50 had two themes: menopause and pelvic disorders.

The objective of the research on menopause, begun at the beginning of the 1990s, was to improve our understanding of the factors involved in using and complying with hormone treatment. At that time, the frequency of hormone replacement treatment (HRT) use in France was not known, but surveys in North America suggested that its use did not correspond to the relevant guidelines. One originality of the work in the GAZEL Cohort Study was the simultaneous consideration in the analysis of HRT use of numerous factors such as type of medical follow-up (general practitioners or gynecologist, man or woman), women's expectations of HRT, their cosmetic practices, and their representations of menopause. HRT use was shown to be associated with hot flushes, osteoporosis prevention, and anti-aging expectations (Ringa et al, 1994), as well as a "demedicalized" cosmetic usage (Fauconnier et al, 2000). The follow-up at 3, 6, and 10 years showed very strong adhesion to HRT and confirmed the existence of a "healthy user effect", that is, that the women in good health were the most compliant (Ringa et al, 2005). Among women of the same age, self-perceived health was poorer among menopausal women than those still menstruating, and this difference in quality of life was essentially associated with symptoms (Ledésert et al, 1995); hot flushes are influenced more by biomedical factors than by social relations (Duché et al, 2006). The 
importance of healthcare professionals was clear when we studied the use of progestin in premenopausal women, which was more frequent among the women seen by gynecologists and by woman doctors (Ringa et al, 2007). The association between progestin use before menopause and HRT use later suggests a continuum in women's practices.

Following the publication of the results of a vast randomized North American trial in 2002, drug agencies here as elsewhere strongly limited the indications for this treatment, which lost the qualifier "replacement" to become simply hormone treatment (HT) of menopause. The follow-up of the GAZEL women allowed to show that, when taking into account numerous other factors that might affect treatment interruption, the use of hormone treatment fell after 2002, in France as in other countries (Ringa et al, 2009).

Another field of research considered the factors associated with the existence of pelvic disorders in women in their 50s, aiming to assess the impact of these disorders on quality of life, and to analyze the determinants of demand for health care for pelvic disorders. This work made it possible to show that urinary incontinence and pelvic organ prolapse have a significant impact on women's quality of life, such that one can talk of a urinary or pelvic handicap (Saadoun et al, 2006; Fritel et al, 2009). Contrary to generally accepted ideas, stress urinary incontinence, anal incontinence, and prolapse symptoms do not appear to be associated with women's obstetric history or hormonal status (Fritel et al, 2005, 2007).

\section{TRAFFIC ACCIDENTS}

A research project on road traffic accidents began in 1999. Among the first results, the investigators showed that the risk of a traffic accident quadrupled during divorce or separation (Lagarde et al, 2004a) and that people who used to have their traffic tickets "fixed" had a higher risk of accidents involving injury than those who did not (Lagarde et al, 2004b). The role of psychosocial and health factors was also studied, showing the excess risk associated 
with type A personality, that is, those whose behavior is marked by aggression and impatience (Nabi et al, 2005, 2006a). A higher risk of accidents also accompanies some particularly painful diseases (Lagarde et al, 2005; Parmentier et al, 2005). Other analyses studied workrelated traffic accidents and showed the role of fatigue at work (Chiron et al, 2008). another finding was that when cohort members retired, their behavior changed and they drove more safely (Bhatti et al, 2008) and that people in the highest social categories had a higher risk of accident than the other categories (Lenguerrand et al, 2008).

In 2002, France introduced a radical change in its road safety policy. This made it possible to observe changes in driving behavior and show that the cohort members changed their attitudes about road safety and reduced their speed, although drinking-associated driving behavior changed only a little (Nabi et al, 2007; Constant et al, 2007, 2009). Finally, drowsiness at the wheel is responsible for $20 \%$ of all accidents (Nabi et al, 2006b).

\section{OTHER TOPICS}

\section{Work absences and health}

One of the strengths of the GAZEL Cohort Study is the exhaustive individual data on the sickness absences of its volunteers, transmitted by the companies' medical department (Service général de médecine de contrôle, SGMC). This is a valuable source of data on the health of cohort members, followed continuously. These data are unique because of some unusual features of the EDF-GDF social insurance fund. They are exhaustive and concern all absences, regardless of their duration with the first and last date listed. Moreover, it includes the medical cause of the absence, coded according to the International Classification of Diseases (ICD). Finally, they are collected by the consulting physicians of the EDF-GDF insurance fund, independently of the subjects, thus avoiding, to some extent, potential recall 
bias by the volunteers or their lack of knowledge of their diagnosis. Diverse studies of the GAZEL Cohort Study widely used absenteeism data.

In some research projects, absence is the health event studied, and the researchers look at the effects of diverse risk factors (personal, occupational or social) on absences for all causes or for specific causes (e.g., musculoskeletal diseases or mental health). Studies have thus analyzed the effects on sick leaves for depression of antihyperlipidemic treatment (Boumendil \& Tubert, 1995) or exposure to psychosocial factors at work (Niedhammer et al, 1998). Daytime somnolence (Philip et al, 2001) and insomnia (Philip et al, 2006) have also been shown associated with an increase in all causes sickness.

In related studies, GAZEL Cohort Study researchers have showed that psychosocial factors at work and social relations exert independent effects on sickness absence (Melchior et al, 2003), that working conditions partially explain the different rates of sickness absence according to social categories, sometimes to a large extent, as for musculoskeletal diseases and mental health problems (Melchior et al, 2005), and that the combination of working conditions and family constraints has an effect on sickness absences for psychiatric reasons (Melchior et al, 2007). Risk factors for sickness absence in subjects with low back pain were also examined (Tubach et al, 2002).

In other cases, absences are considered as a risk factor, a predictor of subsequent health events. A consortium of researchers from different countries (England, Finland, France, and Sweden) developed a research program along this approach; the first results showed the predictiveness of sickness absence for mortality (Ferrie et al, 2009), chronic diseases (Kivimaki et al, 2008), depression (Melchior et al, 2009a), and poor self-rated health (Vahtera et al, 2009). 


\section{Psychological factors and health}

In 1993, a group of researchers collected a set of personality scales by self-administered questionnaire: the Jenkins Activity Survey, which measures type A behavior, the Buss and Durkee Hostility Inventory, the Center for Epidemiologic Studies-Depression (CES-D) scale, and the Grossarth-Maticek and Eysenck Personality Questionnaire (Consoli et al, 1993). These data, beyond their use as adjustment variables in a broad range of studies on diverse topics, were the object of work about the health effects of psychological factors.

The analysis of the respective roles of psychosocial factors at work and subjects' psychological characteristics vis-à-vis depressive mood showed that the former had a negative effect on depressive mood in both genders when the latter was taken into account (Paterniti et al, 2002). Moreover, cognitive hostility has been shown to explain part of the relation between depressive mood and mortality (Lemogne et al, 2009). Some characteristics of the psychological profile were shown to be a risk factor for traffic accidents: a Type A profile was associated with the risk of accident (Nabi et al, 2005). Although overall aggression/hostility personality traits did not predict traffic accidents, irritability and negativism did (Nabi et al, 2006). Some personality factors predicted all-cause, externalcause, and cardiovascular mortality and contributed to social inequalities in health in men, but had little explanatory power in women (Nabi et al, 2008a; Nabi et al, 2008b).

\section{Determinants of the development of alcohol drinking behavior}

Alcohol drinking habits and their relation to other personal and social characteristics are unique to each country. Accordingly, in the British Whitehall II cohort, excessive consumption was from 1.5 to 3 times more common in men with a high socioeconomic status than among their underlings, while the inverse trend was see in the GAZEL Cohort Study (Fuhrer et al, 2002). On the other hand, despite long-time interest, little is know about the 
health effects of the lifelong course of alcohol consumption, and numerous points are debated today.

The annual collection of standardized data about the consumption of alcoholic beverages by the men and women participating in the GAZEL Cohort Study over a very long period (20 years) has made it possible to study the course of drinking as a function of social position, social and occupational environment, and their modifications throughout the participants' careers. Studies have shown the complex relations that exist between working conditions, social and occupational trajectory, and changes in drinking behavior (Leclerc et al, 1994), as well as the role of health status and working conditions as a predictor of subsequent changes in drinking levels (Zins et al, 1999). Changes in alcohol consumption observed around important life events were also analyzed: consumption is lower in divorced women, while marriage is associated with its increase (Zins et al, 2003a); the percentage of heavy drinkers increases among men at retirement, regardless of their birth generation, and this increase is associated with social and occupational status, with the percentage of heavy drinkers increasing more among managers than supervisory or operating employees (Zins et al, 2003b). More recent studies report that while behavior related to at-risk automobile driving has fallen in recent years, excessive alcohol consumption before driving has not (Constant et al, 2009a; Constant et al, 2009b).

\section{Sleep disorders}

The annual collection of data about sleep disorders has made it possible to conduct several studies. Sleep disorders were associated with nighttime work (Moneta et al, 1996) and with sickness absences (Philip et al, 2001). Driving a vehicle while feeling sleepy is associated with the risk of a traffic accident (Nabi et al, 2006), and insomnia is accompanied by a poorer quality of life (Philip et al, 2006). The collection of a sleep diary from a subset of the cohort also allowed to observe the relations between being a "morning" or "evening" type person 
and self-rated health status and disease reporting (Taillard et al, 2001). Finally, it appears that retirement is associated with a strong reduction in sleep disorders, essentially due to the disappearance of unfavorable working conditions (Vahtera et al, 2009).

\section{Retirement}

At inception, in January 1989, all the participants were working at EDF-GDF. Over the years, the number of retirees has increased, and on 1 January 2008 , less than $2 \%$ of the men and less than $22 \%$ of the women in the cohort were still working. The follow-up of the subjects has thus extended from their period of occupational activity to beyond their retirement, and we now have the distance necessary to study outcomes for participants long after their retirement.

Several recent studies in the GAZEL Cohort Study have looked at diverse aspects related to this major event affecting volunteers' work, social, and family lives. Changes in alcohol consumption in the period around retirement have been analyzed (Zins et al, 2003b); this study continues, considering longer periods since retirement. At-risk alcohol consumption related to driving behavior has persisted, while other dangerous driving behaviors have diminished (Bhatti et al, 2008). Continuation of social activities after retirement was associated with better health, except among those who had to care for their own parents (Wahrendorf et al, 2008). Among the major findings are the substantial improvement in selfrated health status (Westerlund et al, 2009) and the strong reduction in sleep disorders (Vahtera et al, 2009) after retirement, which were essentially explained by the end of exposure to unfavorable working conditions.

\section{Methodological work}

Since its origin, diverse methodological projects have accompanied the GAZEL Cohort Study. Essential for the continuous improvement of the quality of the epidemiologic work in 
the cohort, these often have a more general interest, and their results may be useful in other contexts.

The selection effects associated with volunteering at inclusion and during follow-up have been analyzed in especially favorable conditions because of the availability from EDF-GDF departments of socioeconomic, occupational, and medical data about both the participants and non-participants, both at the establishment of the cohort and during follow-up. At inception, higher participation was associated with being male, marriage, children, managerial status, and residence in particular regions. Among men, lower participation was associated with sick leave in the year before recruitment and afterwards; participation was also negatively associated with several groups of diseases and with mortality, especially for alcohol-related diseases. Overall, the most important determinants of participation were cultural factors and lifestyle behaviors. During follow-up, higher response rates to the annual questionnaire were associated with gender (male), age (older), managerial status, and retirement. Smoking and alcohol drinking at baseline were associated with lower participation. Subjects who had at least three sick-leaves during the two years preceding or following the questionnaire were less likely to respond, especially for absence for psychiatric and alcohol-related diseases among men. Those who had rated their health as poor at baseline were less prone to respond during follow-up. Attrition among men was associated with cancer and coronary heart disease. Finally, most variables that predicted initial participation were associated with continued participation, but health problems strongly predicted attrition, while socioeconomic factors played a weaker role (Goldberg et al, 2001, 2006).

Diverse questionnaires and scales were developed or validated in a French version: personality questionnaires (Consoli et al, 1993), a structured diagnostic interview to identify depressive episodes (Duburcq et al, 1999), and a diagnostic questionnaire for migraine (Nachit-Ouinekh F et al, 2005). French versions of two questionnaires widely used 
internationally to assess exposure to psychosocial factors at work were established and validated for the first time in the GAZEL Cohort Study: Karasek's Job Content Questionnaire (Niedhammer, 2002), and Siegrist's Effort/Reward Imbalance scale (Niedhammer et al, 2000); GAZEL data about the latter have been included in international analyses intended to improve the transcultural comparability of the measurement of stress at work (Tsutsumi et al, 2009). Factors associated with self-reporting of weight and height (Niedhammer et al, 2000) and of chronic diseases (Metzger et al, 2002) were also studied.

Statistical work has also aimed at improving the ability to take into account the longitudinal nature of the data and their repeated collection, which involves the existence of missing data (Guéguen et al, 2000; Nakache et al, 2004) and to assess the effects of confounding due to smoking in the study of various diseases (Lagorio et al, 1992).

The establishment of a biobank associated with the cohort was also the occasion to deepen our understanding of the logistic and practical aspects of this research tool (Zins et al, 2003).

\section{Miscellaneous research}

The diversity of the data collected in GAZEL has made it possible to perform studies on various topics according to the interest of different researchers.

Migraine was the topic of a research project covering a subsample of the cohort (Michel et al, 1997a; Michel et al, 1997b; Dartigues et al, 1998; Nachit-Ouinekh et al, 2005). Diverse characteristics of left-handers have been studied (Faurie et al, 2006; Faurie et al, 2008). Selfrated health status, an indicator widely used in epidemiology, was also the object of detailed analyses of its associations with incident morbidity (Goldberg et al, 2001) and with numerous risk factors of diverse types (Singh-Manoux et al, 2006).

Special mention should be made of the study of the psychological disorders of the children of cohort participants. A project begun in 1991 allowed the inclusion of more than 2500 children 
then aged from 4 to 16 years, who were first followed via their parent GAZEL Cohort Study volunteer, and then directly as they grew older. Several topics were covered: contacts with health and mental health care providers and special education personnel for psychological reasons (Fombonne et al, 1997a, 1997b), symptoms of hyperactivity (Galéra et al, 2005), consumption of tobacco, alcohol, and illegal drugs (Melchior et al, 2008; Galéra et al, 2008, Melchior et al, 2009b), suicidal behavior (Galéra et al, 2008), and school trajectory (Galéra et al, 2009). These subjects, who have recently become young adults, have been asked to participate directly in an independent cohort as part of the "Tempo" project.

\section{Descriptive studies}

Composed as it is of volunteer EDF-GDF employees, the GAZEL Cohort Study is not a representative sample of any population. It is therefore a priori not an appropriate support for descriptive studies. Nonetheless, the participants in the cohort are "ordinary" French people in many respects, and numerous phenomena that can be observed through them are not biased by the selection effects associated with their employment at the company or their participation in the cohort. For this reason some descriptive studies have taken advantage of the diversity and wealth of the data collected about this large sample residing across the entire country. Accordingly, studies have examined the geographic distribution of the prevalence of diseases or risk factors (Annesi \& Frette, 1990; Dang Tran et al, 1994, 1998) and the use of diverse types of drugs (Boumendil, 1994; Boumendil \& Mugnier, 1998; Marissal et al, 2000; Ringa et al, 2005, 2007, 2009; Gayet-Ageron et al, 2005). The frequency of some diseases (Michel et al, 1997) and of handedness (Faurie et al, 2008), and the number of women likely to benefit from bone density testing (Amamra et al, 2004a, 2004b) have been estimated, as has the cost of diverse diseases (Dartigues et al, 1998; Selke et al, 2003). 


\section{AgING, A DEVELOPING THEME}

A particularly important point is that the GAZEL Cohort Study is one of the rare cohorts from which numerous aspects of aging can be studied from relatively early in life, since the subjects have been closely followed from a fairly young age. Most cohorts that study aging are composed of subjects at least 60 or 65 years of age at inception. The younger age at study outset permits thorough study of early predictive factors of aging of various types among volunteers who are aged today from 55 to 70 years and will continuously be followed-up.

Longitudinal follow-up offers broad possibilities for studying dynamically the delayed effects on aging of numerous factors (developing frailty, cancer, chronic diseases, and mental health) that can lead to inactivity and isolation, as well as factors and mechanisms that work together for successful aging or on the contrary cause disabilities or frailty. Although the initial research orientations focus on aging in a population still relatively young, it is planned to observe this population over the very long term, without setting an age limit to the follow-up. Several research projects have begun on musculoskeletal disorders, physical and cognitive performance, mental health, and chronic diseases. Their consequences in terms of disability and social impact will be studied in more detail. These studies will focus on the long-term effects of living conditions and work, lifetime occupational exposure, and on the positive role of social activities and social networks, especially after stopping work.

\section{HOW TO GET ACCESS TO GAZEL COHORT STUDY?}

Any research group, in France or elsewhere, can submit a research proposal to work on the GAZEL Cohort Study. These projects are reviewed by a Scientific Committee, and those selected receive free access to the GAZEL data and subjects. More than 40 research projects have been conducted on this cohort by some 30 research groups from different countries 
(Germany, Belgium, Canada, Great Britain, Sweden, Finland, and USA), many of them currently underway.

Submitting a research proposal involves filling an application form stating the objectives of the study, the description of sample, the methods, the data needed and a timetable. French legal requirements must also be met. The first step would be to contact one of the principal investigators of the GAZEL Cohort Study (MG or MZ). Refer to the GAZEL website: http://www.gazel.inserm.fr/ for further details on the study and the procedures for submitting a research proposal.

\section{ACKNOWLEDGEMENTS}

Many individuals at INSERM have contributed to the GAZEL Cohort Study. We wish to thank: Sébastien Bonenfant, Isabelle Bugel, Geneviève Carole, Jean François Chastang, Mireille Coeuret-Pellicer, Nadine Kaniewski, Sophie Launay, Marie-Hélène Martineau, Marie-José Marne, Jean-François Morcet, Anna Ozguler, Michèle Picciotti, Annie Schmaus. We are grateful to "Électricité de France-Gaz de France" and to the "Caisse centrale d'action sociale du personnel des industries électrique et gazière" for their cooperation and funding over so many years.

\section{REFERENCES}

Amamra N, Berr C., Clavel-Chapelon F, Delcourt C, Delmas P, Derriennic F, Ducimetiere P, Goldberg M, Letenneur L, Rabilloud M, Meunier P, Schott AM. Estimated number of women likely to benefit from bone mineral density measurement in France. Joint Bone Spine, 2004a, $71,5,409-418$.

Amamra N, Berr C, Clavel-Chapelon F, Delcourt C, Delmas P, Derriennic F, Ducimetiere P, Goldberg M, Letenneur L, Rabilloud M, Meunier P, Schott AM. Estimation du nombre de 
femmes françaises à risque d'ostéoporose susceptibles de bénéficier d'une ostéodensitométrie. Revue du Rhumatisme, 2004b, 71, 9, 790-800.

Annesi I, Frette C. Geoepidemiology of asthme in France : data from a large French working population. The European Respiratory Journal, 1990, 3, supp. 10, 2765.

Berkman L, Melchior M, Chastang JF, Niedhammer I, Leclerc A, Goldberg M. Social integration and mortality: a prospective study of French employees of Electricity of FranceGas of France: the GAZEL Cohort. American Journal of Epidemiology, 2004, 159, 2, 167174.

Bhatti J, Constant A, Salmi LR, Chiron M, Lafont S, Zins M, Lagarde E. Impact of retirement on risky driving behaviors and attitudes toward road safety among a large cohort of French drivers (the GAZEL cohort). Scand J Work Envir and Health, 2008, 22, 307-315.

Boumendil E. Descriptive study of lipid modulating drug use in a French professional population. Journal of Clinical Epidemiology, 1994, 47, 10, 1163-1171.

Boumendil E, Mugnier C. Follow-up study of the use of antihypertensive drug treatment and of the population treated. American Journal of Hypertension, 1998, 11, 929-934.

Boumendil E, Tubert-Bitter P. Depression-induced absenteism in relation with antihyperlipidemic treatment : a study using GAZEL cohort data. Epidemiology, 1995, 6, 3, $322-325$.

Chiron M, Bernard M, Lafont S, Lagarde E. Tiring job and work related injury road crashes in the GAZEL cohort. Accid Anal Prev, 2008, 40, 1096-104.

Consoli S, Cordier S, Ducimetiere P. Validation d'un questionnaire de personnalité destiné à repérer des sous-groupes à risque de cardiopathie ischémique ou de cancer dans la cohorte GAZEL. Rev Epidemiol Santé Pub, 1993, 41, 4, 315-326. 
Constant A, Salmi LR, Lafont S, Chiron M, Lagarde E. Road casualties and changes in risky driving behavior in France between 2001 and 2004 among participants in the GAZEL Cohort. Am J Public Health 2009a; 99, 1247-1253.

Constant A, Lafont S, Chiron M, Zins M, Lagarde E, Messiah A. Failure to reduce driving while alcohol intoxicated in France: a 6 year prospective study in the GAZEL Cohort. Addiction 2009b [Epub ahead of print].

Constant A, Salmi LR, Lafont S, Chiron M, Lagarde E. The recent dramatic decline in road mortality in France: how drivers' attitudes towards road traffic safety changed between 2001 and 2004 in the GAZEL cohort. Health Educ Research, 2008, 5, 848-58.

Dang Tran P, Leclerc A, Chastang JF, Goldberg M. Prévalence des problèmes de santé dans la cohorte GAZEL (EDF-GDF) : Répartition et disparités géographiques. Rev Epidemiol Santé Pub, 1994, 4, 42, 285-300.

Dang Tran P, Leclerc A, Chastang JF, Goldberg M. Regional disparities in cardiovascular risk factors in France: A five-year analysis of the GAZEL cohort. Eur J Epidemiol, 1998, 14, 535543.

Dartigues JF, Michel P, Lindoulsi AC, Dubroca B, Henry P. Comparative view of the socioeconomic impact of migraine versus low back pain. Cephalalgia, 1998, suppl 21, 26-29. Duburcq A, Blin P, Charpak Y, Blachier C, Allicar MP, Bouhassira M, Hergueta T, Lecrubier Y. Utilisation d'un entretien diagnostique structuré pour identifier les épisodes dépressifs dans une étude épidémiologique : validation interne a posteriori. Rev Epidemiol Santé Pub, 1999, $47,5,455-463$.

Duche L, Ringa V, Melchior M, Varnoux N, Piault S, Zins M, Breart G. Hot flushes, common symptoms and social relations among middle aged non-menopausal French women in the GAZEL cohort. Menopause, 2006, 13, 4, 592-599. 
Fauconnier A, Ringa V, Delanoë D, Falissard B, Breart G. Use of hormone replacement therapy: women's representations of menopause and beauty care practices. Maturitas, 2000, $35,215-228$.

Faurie C, Bonenfant S, Goldberg M, Hercberg S, Zins M. Raymond M. Socio-economic status and handedness in two large cohorts of French adults. Br J Psychol, 2008, 99, 533-554. Faurie C, Bonenfant S, Goldberg M, Hercberg S, Zins M, Raymond M. Socio-economic status and handedness in two large cohorts of French adults. Evolution and Human Behavior, 2006, 27, 457-472.

Ferrie JE, Vahtera J, Kivimäki M, Westerlund H, Melchior M, Alexanderson K, Head J, Chevalier A, Leclerc A, Zins, Goldberg M, Singh-Manoux A. Diagnosis-specific sickness absence and all-cause mortality in the GAZEL Study. J Epidemiol Community Health, 2009, $63,50-55$

Fombonne E, Vermeersch S. Les enfants de la cohorte GAZEL : I. Prévalence des contacts avec le système médico-éducatif pour des motifs psychologiques, et facteurs associés. Rev Epidemiol Santé Pub, 1997, 45, 29-40.

Fombonne E, Vermeersch S. Les enfants de la cohorte GAZEL : II. Motifs des contacts avec le système médico-éducatif, par âge et sexe. Rev Epidemiol Santé Pub, 1997, 45, 107-115. Fritel X, Ringa V, Varnoux N, Zins M, Bréart G. Mode of Delivery and Fecal Incontinence at Midlife: A Study of 2,640 Women in the GAZEL Cohort. Obstet Gynecol, 2007, 110:31-38.

Fritel X, Varnoux N, Zins M, Bréart G, Ringa V. Symptomatic Pelvic Organ Prolapse at Midlife, Quality of Life, and Risk Factors. Obstet Gynecol, 2009,113, 609-616.

Fritel X, Ringa V, Varnoux N, Fauconnier A, Piault S, Breart G. Mode of delivery and severe stress incontinence. a cross-sectional study among 2,625 perimenopausal women. BJOG, $2005,112,12,1646-1651$. 
Fuhrer R, Shipley MJ, Chastang JF, Schmaus A, Niedhammer I, Stansfeld SA, Goldberg M, Marmot MG. Socioeconomic position, health, and possible explanations: a tale of two cohorts. Am J Pub Health, 2002, 92, 8, 1290-1294.

Galéra C, Bouvard MP, Encrenaz G, Messiah A, Fombonne E. Hyperactivity-inattention symptoms in childhood and suicidal behaviors in adolescence: the Youth Gazel Cohort. Acta Psychiatr Scand, 2008, 118, 480-9.

Galera C, Bouvard MP, Messiah A, Fombonne E. Hyperactivity-inattention symptoms in childhood and substance use in adolescence: The Youth Gazel cohort. Drug Alcohol Depend, 2008, 94, 30-7.

Galéra C, Melchior M, Chastang JF, Bouvard MP, Fombonne E. Childhood and adolescent hyperactivity-inattention symptoms and academic achievement 8 years later: the GAZEL Youth study. Psychol Med, 2009, 1:1-12.

Galera C, Fombonne E, Chastang JF, Bouvard MP. Childhood hyperactivity-inattention symptoms and smoking in adolescence. Drug and Alcohol Dependence, 2005, 78, 1, 101-108. Gayet-Ageron A, Amamra N, Ringa V, Tainturier V, Berr C, Clavel-Chapelon F, Delcourt C, Delmas PD, Ducimetiere P, Schott AM. Estimated numbers of postmenopausal women treated by hormone therapy in France. Maturitas, 2005, 52, 3-4, 296-305.

Goldberg M, Leclerc A, Bonenfant S, Chastang JF, Schmaus A, Kaniewski N, Zins M. Cohort profile: the GAZEL Cohort Study. Int J Epid, 2007, 36, 32-39.

Goldberg M, Chastang JF, Leclerc A, Zins M, Bonenfant S, Bugel I, Kaniewski N, Schmaus A, Niedhammer I, Piciotti M, Chevalier A, Godard C, Imbernon E. Socioeconomic, demographic, occupational and health factors associated with participation in a long-term epidemiologic survey. A prospective study of the French GAZEL cohort and its target population. American Journal of Epidemiology, 2001, 154, 4, 373-384. 
Goldberg M, Chastang JF, Zins M, Niedhammer I, Leclerc A. Health problems were the strongest predictors of attrition during follow up of the GAZEL cohort. J Clin Epidemiol, 2006, 59, 1213-21.

Goldberg M, Leclerc A, Chastang JF, Morcet JF, Marne MJ, Luce D, Boumendil E. Mise en place d'une cohorte épidémiologique à Electricité de France - Gaz de France. Recrutement des volontaires. Principales caractéristiques de l'échantillon. Rev Epidemiol Santé Pub, 1990, 38, 265-268 and 378-380.

Goldberg M, Leclerc A, Chastang JF, Morcet JF, Schmaus A, Marne MJ, Luce D, Boumendil E. Une cohorte épidémiologique à EDF-GDF : l'opération 20000 volontaires pour la recherche médicale. AIPPS, Hommes et Santé, 1991, 60, 7-14.

Goldberg P, Gueguen A, Schmaus A, Nakache JP, Goldberg M. Longitudinal study of associations between perceived health status and self-reported diseases in the French GAZEL cohort. J Epid Com Health, 2001, 55, 233-238.

Gueguen A, Zins M, Nakache J.P. Utilisation des modèles marginaux et des modèles mixtes dans l'analyse de données longitudinales (1992-1996) concernant mariage et consommation d'alcool des femmes de la cohorte GAZEL. Revue de Statistique Appliquée, 2000, XLVIII, 3, $57-73$.

Hyde M, Jacub J, Melchior M, Van Oort F, Weyers, S. A comparison of the effects of low childhood socio-economic position and low adulthood socio-economic position on self-rated health in four European studies. J Epid Com Health, 2006, 60, 882-6.

Kivimäki M, Head J, Ferrie JE, Singh-Manoux A, Westerlund H, Vahtera J, Leclerc A, Melchior M, Chevalier A, Alexanderson K, Zins M, Goldberg M. Sickness absence as a prognostic marker for common chronic conditions: Analysis of mortality in the GAZEL study. Occup Environ Med 2008, 65, 820-826. 
Lagarde E, Chastang JF, Gueguen A, Coeuret-Pellicer M, Chiron M, Lafont S. Emotional stress and traffic accidents: the impact of separation and divorce. Epidemiology, 2004, 15, 6, $762-766$.

Lagarde E, Chastang JF, Lafont S, Coeuret-Pellicer M, Chiron M. Pain and pain treatment were associated with traffic accident involvement in a cohort of middle-aged workers. Journal of Clinical Epidemiology, 2005, 58, 5, 524-531.

Lagarde E, Chiron M, Lafont S. Traffic ticket fixing and driving behaviours in a large French working population. Journal of Epidemiology and Community Health, 2004, 58, 562-568.

Lagorio S, Guenel P, Luce D, Leclerc A, Morcet JF, Goldberg M. Estimated confounding from smoking in a cohort of 20,000 French electrical workers. Epid Prev, 1992, 50, 43-51.

Leclerc A, Tubach F, Landre MF, Ozguler A. Personal and occupational predictors of sciatica in the GAZEL cohort. Occup Med, 2003, 53, 6, 384-391.

Leclerc A, Zins M, Bugel I, Chastang JF, David S, Morcet JF, Goldberg M. Consommation de boissons alcoolisées et situation professionnelle dans la cohorte GAZEL (EDF-GDF). Arch Mal Prof, 1994, 55, 7, 509-517.

Ledesert B, Ringa V, Breart G. Menopause and perceived health status among the women of the French GAZEL cohort. Maturitas, 1994, 20, 113-120.

Lemogne C, Nabi H, Zins M, Cordier S, Ducimetière P, Bonenfant S, Consoli SM. Cognitive hostility may partially explain the association between depressive mood and mortality: Evidence from the French GAZEL cohort study. Psychotherapy and Psychosomatics 2009 (in press).

Lenguerrand E, Martin JL, Chiron M, Lagarde E, Laumon B. Road crash involvement and professional status: a prospective study using the French Gazel cohort. Accid Anal Prev, $2008,40,126-36$. 
Marissal JP, Selke B, Lebrun T. Economic assessment of the secondary prevention of ischaemic events with lysine acetylsalicylate. Pharmacoeconomics, 2000, 18, 185-200.

Melchior M, Berkman LF, Niedhammer I, Zins M, Goldberg M. The mental health effects of multiple work and family demands: a prospective study of psychiatric sickness absence in the French GAZEL Study. Soc Psychiatry Psychiatr Epidemiol, 2007, 42, 573-582.

Melchior M, Chastang JF, Goldberg P, Fombonne E. High prevalence rates of tobacco, alcohol and drug use in adolescents and young adults in France: results from the GAZEL Youth Study. Addict Behav, 2008, 33, 122-133.

Melchior M, Ferrie J, Alexandersson K, Goldberg M, Kivimaki M, Singh-Manoux A, Vahtera J, Westerlund H, Zins M, Head J. Using Sickness Absence Records to Predict Future Depression in a Working Population: Prospective Findings From the GAZEL Cohort. Am $\mathbf{J}$ Pub Health, 2009a, 99, 1417-1422.

Melchior M, Chastang JF, Mackinnon D, Galéra C, Fombonne E. The intergenerational transmission of tobacco smoking-The role of parents' long-term smoking trajectories. Drug Alcohol Depend 2009b. [Epub ahead of print]

Melchior M, Berkman L, Niedhammer I, Chea M, Goldberg M. Social relations and selfreported health: a prospective analysis of the French GAZEL cohort. Soc Sc Med, 2003, 56, 1817-1830.

Melchior M, Berkman LF, Kawachi I, Krieger N, Zins M, Bonenfant S, Goldberg M. Lifelong socioeconomic trajectory and premature mortality (35-65) in France: Findings from the GAZEL cohort study. J Epid Com Health, 2006, 60, 937-944.

Melchior M, Goldberg M, Krieger N, Kawachi I, Menvielle G, Zins M, Berkman L. Occupational class, occupational mobility and cancer incidence among middle-aged men and 
women: a prospective study of the French GAZEL cohort. Cancer Causes and Control, 2005, $16,515-524$.

Melchior M, Krieger N, Kawachi I, Berkman L, Niedhammer I, Goldberg M. Work factors and occupational class disparities in sickness absence: findings from the GAZEL cohort study. Am J Pub Health, 2005, 95, 7, 1206-1212.

Melchior M, Niedhammer I, Berkman L, Goldberg M. Do psychosocial work factors and social relations exert independent effects on sickness absence? A six year prospective study of the GAZEL cohort. J Epid Com Health, 2003, 57, 285-293.

Metzger MH, Goldberg M, Chastang JF, Leclerc A, Zins M. Factors associated with selfreporting of chronic health problems in the French GAZEL cohort. J Clin Epid, 2002, 55, 4859.

Michel P, Dartigues JF, Lindoulsi AC, Henry P. Loss of productivity and quality of life in migraine sufferers among French workers: results from the GAZEL cohort. Headache, 1997a, 37, 71-78.

Michel P, Dubroca B, Dartigues JF, El Hasnaoui A, Henry P. Frequency of severe attacks in migraine sufferers of the GAZEL cohort. Cephalalgia, 1997b, 17, 863-866.

Moneta G, Leclerc A, Chastang JF, Dang Tran P, Goldberg M. Time-trend of sleep disorder in relation to night work: a study of sequential one-year prevalences within the GAZEL cohort. J Clin Epid, 1996, 49, 10, 1133-1141.

Nabi H, Kivimäki M, Marmot MG, Ferrie J, Zins M, Ducimetière P, Consoli SM, SinghManoux A. Does personality explain social inequalities in mortality? The French GAZEL Cohort Study. Int. J. Epid, 2008a, 37, 591-602. 
Nabi H, Kivimäki M, Zins M, Elovainio M, Consoli SM, Cordier S, Ducimetière P, Goldberg M, Singh-Manoux A. Does personality predict mortality? Results from the GAZEL French prospective cohort study. Int J Epid. 2008b 37, 386-96.

Nabi H, Salmi LR, Lafont S, Chiron M, Zins M, Lagarde E. Attitudes associated with behavioral predictors of serious road traffic crashes: results from the GAZEL Cohort. Inj Prev, 2007, 13, 26-31.

Nabi H, Consoli SM, Chastang JF, Chiron M, Lafont S, Lagarde E. Type A Behavior Pattern, Risky Driving Behaviors, and Serious Road Traffic Accidents: A Prospective Study of the GAZEL Cohort. Am J Epid, 2005, 161, 9, 864-870.

Nabi H, Consoli SM, Chiron M, Lafont S, Chastang JF, Zins M, Lagarde E. Aggressive/hostile personality traits and injury accidents: an eight-year prospective study of a large cohort of French employees - The GAZEL cohort. Psychological Medicine, 2006, 36, 3, 365-373.

Nabi H, Guéguen A, Chiron M, Lafont S, Zins M, Lagarde E. Awareness of driving while sleepy and road traffic accidents: prospective study in GAZEL cohort. BMJ, 2006, 333, 7579.

Nachit-Ouinekh F, Chrysostome V, Henry P, Sourgen C, Dartigues JF, El Hasnaoui A. Variability of reported headache symptoms and diagnosis of migraine at 12 months. Cephalalgia, 2005, 25, 2, 117-123.

Nachit-Ouinekh F, Dartigues JF, Chrysostome V, Henry P, Sourgen C, El Hasnaoui A. Evolution of Migraine After a 10-Year Follow-up. Headache, 2005, 45, 1280-1287.

Nakache JP, Gueguen A, Zins M, Goldberg M. Analyse de données de survie groupées avec covariables dépendant du temps : application à l'étude de l'effet prédictif de l'état de santé 
perçu sur le décès, chez les hommes de la Cohorte GAZEL observés dans la période 19891999. Revue de Statistique Appliquée, 2004, 211, 27-49.

Niedhammer I. Psychometric properties of the French version of the Karasek Job Content Questionnaire: a study of the scales of decision latitude, psychological demands, social support, and physical demands in the GAZEL cohort. International Arch Occup Envir Health, $2002,75,3,129-144$.

Niedhammer I, Bugel I, Bonenfant S, Goldberg M, Leclerc A. Validity of self-reported weight and height in the French GAZEL cohort. Int J Obesity, 2000, 24, 1111-1118.

Niedhammer I, Bugel I, Goldberg M, Leclerc A, Gueguen A. Psychosocial factors at work and sickness absence in the GAZEL cohort: a prospective study. Occup Envir Med, 1998, 55, 735-741.

Niedhammer I, Chea M. Psychosocial factors at work and self reported health: comparative results of cross sectional and prospective analyses of the French GAZEL cohort. Occup Envir Med, 2003, 60, 509-515.

Niedhammer I, David S, Bugel I, Chea M. Catégorie socioprofessionnelle et exposition aux facteurs psychosociaux au travail dans une cohorte professionnelle. Travailler, 2000, 5 , 2345.

Niedhammer I, Goldberg M, Leclerc A, Bugel I, David S. Psychosocial factors at work and subsequent depressive symptoms in the GAZEL cohort. Scand J Work Envir Health, 1998, 24, 3, 197-205.

Niedhammer I, Goldberg M, Leclerc A, David S, Bugel I, Landre M.F. Psychosocial work environment and cardiovascular risk factors in an occupational cohort in France. J Epid Com Health, 1998, 52, 93-100. 
Niedhammer I, Siegrist J, Landre MF, Goldberg M, Leclerc A. Etude des qualités

psychométriques de la version française du modèle du Déséquilibre Efforts/Récompenses. Rev Epid Sante Pub, 2000, 48, 419-437.

Niedhammer I, Tek ML, Starke D, Siegrist J. Effort-reward imbalance model and selfreported health: cross-sectional and prospective findings from the GAZEL cohort. Soc Sc Med, 2004, 58, 8, 1531-1541.

Parmentier G, Chastang JF, Nabi H, Chiron M, Lafont S, Lagarde E. Road mobility and the risk of road traffic accident as a driver. The impact of médical conditions and life events. Accident, Analysis and Prevention, 2005, 37, 6, 1121-1134.

Paterniti S, Niedhammer I, Lang T, Consoli SM. Psychosocial factors at work, personality traits and depressive symptoms. Longitudinal results from the GAZEL Study. Br J Psychiatry, $2002,181,2,111-117$.

Philip P, Leger D, Taillard J, Querala-Salva MA, Niedhammer I, Mosqueda JG, Bioulac B, Gerard D. Insomniac complaints interfere with quality of life but not with absenteeism: Respective role of depressive and organic comorbidity. Sleep Med, 2006, 7, 585-91. Philip P, Taillard J, Niedhammer I, Guilleminault C, Bioulac B. Is there a link between subjective daytime somnolence and sickness absenteeism? A study in a working population. J Sleep Res, 2001, 10, 111-115.

Plouvier S, Renahy E, Chastang JF, Bonenfant S, Leclerc A. Biomechanical strains and low back disorders: quantifying the effects of the number of years of exposure on various types of pain. Occup Environ Med, 2008 65, 268-74.

Plouvier S, Leclerc A, Chastang JF, Bonenfant S, Goldberg M. Socioeconomic position and low-back pain--The role of biomechanical strains and psychosocial work factors in the GAZEL cohort. Scand J Work Environ Health. 2009;35:429-36. 
Ribet C, Lang T, Zins M, Bingham A, Ferrieres J, Arveiler D, Amouyel P, Bonenfant S, Chastang JF, Goldberg M., Ducimetiere P. Do cardiovascular risk factors in men depend on their spouses' occupational category? Eur J Epid, 2001, 17, 4, 347-356.

Ribet C, Zins M, Gueguen A, Bingham A, Goldberg M, Ducimetiere P, Lang T. Occupational mobility and risk factors in working men: selection, causality or both? Results from the GAZEL study. J Epid Com Health, 2003, 57, 11, 901-906.

Ringa V, Fritel X, Varnoux N, Zins M, Piault S, Quelen C. Association between premenopausal progestogen use and postmenopausal hormonal therapy in the GAZEL cohort. Maturitas, 2007, 58, 216-225.

Ringa V, Ledesert B, Breart G. Determinants of hormone replacement therapy among postmenopausal women enrolled in the French GAZEL cohort. Osteoporosis International, 1994, 4, 16-20.

Ringa V, Varnoux N, Piault S, Breart G. Hormone therapy use among postmenopausal French women before the publication of the Women's Health Initiative Study: duration of use and factors associated with discontinuation. Fertility And Sterility, 2005, 83, 6, 1771-1779.

Ringa V, Fritel X, Varnoux N, Zins M, Quelen C, Bouyer J. Discontinuation of hormone therapy in the French GAZEL cohort - 1990-2006. Fertility and Sterility, 2009 [Epub ahead of print].

Saadoun K, Ringa V, Fritel X, Varnoux N, Zins M, Breart G. Negative impact of urinary incontinence on quality of life, a cross-sectional study among women aged 49-61 years enrolled in the GAZEL Cohort. Neurourol Urodyn, 2006, 25:696-702.

Sanchez-Ortuno M, Moore N, Taillard J, Valta C, Leger D, Bioulac B, Philip P. Sleep duration and caffeine consumption in a French middle-aged working population. Sleep Medicine, 2005, 6, 3, 247-251. 
Selke B, Durand I, Marissal JP, Chevalier D, Lebrun T. Cost of colorectal cancer in France in 1999. Gastr Clin Biol, 2003, 27, 22-27.

Siegrist J, Starke D, Chandola T, Godin I, Marmot M, Niedhammer I, Peter R. The measurement of effort-reward imbalance at work: European comparisons. Soc Sc Med, 2004, $58,8,1483-1499$.

Silhol R, Zins M, Chauvin P, Chaix B Investigating the spatial variability in incidence of coronary heart disease in the Gazel Cohort: the impact of area socioeconomic position and mediating role of risk factors. J Epidemiol Community Health, 2009 [Epub ahead of print] Singh-Manoux A, Dugravot A, Shipley MJ, Ferrie JE, Martikainen P, Goldberg M, Zins M. The association between self-rated health and mortality in different socioeconomic groups in the GAZEL cohort study. Int J Epid, 2007, 36, 1222-1228.

Singh-Manoux A, Guéguen A, Ferrie J, Shipley M, Martikainen P, Bonenfant S, Goldberg M, Marmot M. Gender paradox: does the association between morbidity and mortality differ in middle-aged men and women? Am J Pub Health, 2008, 98 2251-2257.

Singh-Manoux A, Shipley MJ, Zins M, Ferrie JE. Does personality explain social inequalities in mortality? The French GAZEL cohort study. Letter to the Editor. Int J Epid, 2008, 1-2.

Singh-Manoux A, Martikainen P, Ferrie JE, Zins M, Marmot M, Goldberg M. What does selfrated-health measure? - Results from the British Whitehall II and French GAZEL cohort studies. J Epid Com Health. 2006, 60, 364-72.

Stringhini S, Dugravot A, Kivimaki M, Shipley M, Zins M, Goldberg M, Ferrie JE, SinghManoux A. Multiple measures of childhood socioeconomic circumstances and mortality: Evidence from the British Whitehall II and French GAZEL studies. Int J Epid 2009 (in press). Taillard J, Philip P, Chastang JF, Diefenbach K, Bioulac B. Is self-reported morbidity related to the circadian clock ? J Biol Rhythms, 2001, 16, 2, 183-190. 
Tsutsumi A, Iwata N, Watanabe N, De Jonge J, Pikhart H, Fernández-López JA, Xu L, Peter

R, Knutsson A, Niedhammer I, Kawakami N, Siegrist J. Application of item response theory to achieve cross-cultural comparability of occupational stress measurement. Int J Methods Psychiatr Res, 2009, 18, 58-67.

Tubach F, Beaute J, Leclerc A. Natural history and prognostic indicators of sciatica. J Clin Epid, 2004, 57, 2, 174-179.

Tubach F, Leclerc A, Landre MF, Pietri-Taleb F. Risk factors for sick leave due to low back pain: a prospective study. J Occup Envir Med, 2002, 44, 5, 451-458.

Vahtera J, Westerlund H, Ferrie J, Head J, Melchior M, Singh-Manoux A, Zins M, Goldberg M, Alexanderson K, Kivimäki M. All-cause and diagnosis-specific sickness absence as a predictor of sustained sub-optimal health: a 14-year follow-up in the GAZEL cohort. J Epid Com Health 2009 (in press).

Vahtera J, Westerlund H, Hall M, Sjösten N, Kivimäki M, Salo P,. Ferrie JE, Jokela M, Pentti J, Singh-Manoux A, Goldberg M, Zins M. Effect of retirement on sleep disturbances: the GAZEL prospective cohort study. Sleep 2009;32:1459-1466.

Wahrendorf M, Ribet C, Zins M, Siegrist J. Social productivity and depressive symptoms in early old age-results from the GAZEL study. Aging Ment Health, 2008, 12, 310-16.

Westerlund H, Kivimäki Mika, Singh-Manoux A, Melchior M,. Ferrie JE, Pentti J, Jokela M, Leineweber C, Goldberg M, Zins M, Vahtera J. Self-rated health before and after retirement: findings from the GAZEL Cohort Study. The Lancet, 2009;374:1889-1896.

Zins M, Carle F, Bugel I, Leclerc A, Di Orio F, Goldberg M. Predictors of change in alcohol consumption among Frenchmen of the GAZEL study cohort. Addiction, 1999, 94, 3, 385-395. 
Zins M, Gueguen A, Leclerc A, Goldberg M. Alcohol consumption and marital status of French women in the GAZEL cohort: a longitudinal analysis between 1992 and 1996. Journal of Studies on Alcohol, 2003a, 64, 784-789.

Zins M, Gueguen A, Leclerc A, Goldberg M. Place du passage à la retraite parmi les déterminants socioprofessionnels de la consommation de boissons alcoolisées des volontaires de la cohorte GAZEL. Déviance et société, 2003b, 27, 3, 257-268.

Zins M, Ozguler A, Bonenfant S, Henny J, Goldberg M. Mise en place d'une banque de matériel biologique associée à la cohorte GAZEL : Aspects logistique et pratique. Rev Epid Sante Pub, 2003, 51, 143-146. 
Table 1: Principal characteristics of the GAZEL cohort at inception (1989)

\begin{tabular}{|c|c|c|c|c|c|}
\hline & \multicolumn{2}{|l|}{ Men } & \multicolumn{2}{|c|}{ Women } \\
\hline & & $\mathrm{N}$ & $\%$ & $\mathrm{~N}$ & $\%$ \\
\hline \multirow[t]{3}{*}{ Birth generation } & $1939-1943$ & 6356 & 42.3 & 1379 & 24.6 \\
\hline & 1944-1948 & 8654 & 57.7 & 2037 & 36.3 \\
\hline & $1949-1953$ & --- & --- & 2198 & 39.2 \\
\hline Sex & & 15010 & 100.0 & 5614 & 100.0 \\
\hline \multirow[t]{4}{*}{ Social status at hiring by EDF-GDF } & Manager & 1412 & 9.4 & 231 & 4.1 \\
\hline & Supervisor/intermediate & 1329 & 8.9 & 357 & 6.4 \\
\hline & Non-manual worker & 3203 & 21.4 & 4961 & 88.5 \\
\hline & Manual worker & 9052 & 60.4 & 55 & 1.0 \\
\hline \multirow[t]{4}{*}{ Status social at inclusion } & Manager & 4285 & 28.6 & 432 & 7.7 \\
\hline & Supervisory & 8277 & 55.2 & 3510 & 62.6 \\
\hline & Non-manual worker & 633 & 4.2 & 1625 & 29.0 \\
\hline & Manual worker & 1799 & 12.0 & 36 & 0.6 \\
\hline \multirow[t]{3}{*}{ Smoking status at inclusion } & Smoker & 4632 & 31.0 & 1200 & 24.6 \\
\hline & Non-smoker & 5087 & 34.1 & 3672 & 75.4 \\
\hline & Ex-smoker & 5204 & 34.9 & 654 & 11.8 \\
\hline \multirow[t]{6}{*}{ Alcohol use at inclusion } & Abstinent & 293 & 2.0 & 258 & 4.6 \\
\hline & Occasional & 7370 & 49.1 & 4205 & 74.9 \\
\hline & Light & 2444 & 16.3 & 443 & 7.9 \\
\hline & Moderate & 2754 & 18.3 & 441 & 7.9 \\
\hline & Heavy & 1848 & 12.3 & 132 & 2.4 \\
\hline & Other & 301 & 2.0 & 135 & 2.4 \\
\hline \multirow[t]{3}{*}{ Body mass index at inclusion } & Low & 2709 & 19.1 & 1760 & 33.6 \\
\hline & Average & 8034 & 56.6 & 2932 & 56.0 \\
\hline & High & 3443 & 24.3 & 540 & 10.3 \\
\hline \multirow{3}{*}{$\begin{array}{l}\text { Perceived health status at inclusion } \\
\text { (scale: } 1-8)\end{array}$} & $1-3$ & 10433 & 70.1 & 3671 & 66.4 \\
\hline & $4-5$ & 3755 & 25.2 & 1582 & 28.6 \\
\hline & $6-8$ & 691 & 4.6 & 272 & 4.9 \\
\hline \multirow{4}{*}{$\begin{array}{l}\text { Number disorders reported at inclusion } \\
\text { (from a predefined list) }\end{array}$} & 0 & 3219 & 21.4 & 943 & 16.8 \\
\hline & $1-2$ & 7730 & 51.5 & 2556 & 45.5 \\
\hline & $3-5$ & 3662 & 24.4 & 1693 & 30.2 \\
\hline & $6-10$ & 399 & 2.7 & 422 & 7.5 \\
\hline
\end{tabular}


Table 2: Sources of regular data for all participants

\begin{tabular}{|c|c|c|c|}
\hline Data & Source & Population & Date \\
\hline $\begin{array}{l}\text { Self-administered annual } \\
\text { questionnaire }\end{array}$ & Volunteers & All & Since 1989 \\
\hline Occupational data & GPSO-EDF GDF & $\begin{array}{l}\text { Participants still } \\
\text { working }\end{array}$ & Since 1989 \\
\hline Work absences & SGMC-EDF GDF & $\begin{array}{l}\text { Participants still } \\
\text { working }\end{array}$ & Since 1978 \\
\hline Occupational exposure & $\begin{array}{l}\text { Occupational medicine- } \\
\text { EDF GDF }\end{array}$ & $\begin{array}{l}\text { Participants still } \\
\text { working }\end{array}$ & Since 1994 \\
\hline Standardized health work-up & CES & All & Since 1999 \\
\hline Biobank & CES & All & Since 1999 \\
\hline Health-care utilization & CMCAS & All & Since 2000 \\
\hline Cancer incidence & EDF-GDF SGMC Registry & $\begin{array}{l}\text { Participants still } \\
\text { working }\end{array}$ & Since 1978 \\
\hline $\begin{array}{l}\text { Ischemic heart disease } \\
\text { incidence }\end{array}$ & EDF-GDF SGMC Registry & $\begin{array}{l}\text { Participants still } \\
\text { working }\end{array}$ & Since 1989 \\
\hline Causes of death & CepiDc Inserm & All deaths & Since 1989 \\
\hline
\end{tabular}


Table 3: Principal causes of death (1989-2005) ${ }^{*}$

\begin{tabular}{lrrrr} 
& Men & \multicolumn{3}{c}{ Women } \\
& $\mathrm{N}$ & $\%$ & $\mathrm{~N}$ & $\%$ \\
Cancer & 406 & $48.7 \%$ & 92 & $65.2 \%$ \\
Ischemic heart disease & 86 & $10.3 \%$ & & \\
Other cardiovascular & 75 & $9.0 \%$ & 12 & $8.5 \%$ \\
Suicide & 53 & $6.4 \%$ & 10 & $7.1 \%$ \\
Other violent deaths & 65 & $7.8 \%$ & 6 & $4.3 \%$ \\
Other causes & 148 & $17.8 \%$ & 21 & $14.9 \%$ \\
TOTAL & 833 & $100.0 \%$ & 141 & $100.0 \%$
\end{tabular}

*Last year for which causes of death are currently available 
Figure 1: Response rate to the self-administered annual questionnaire

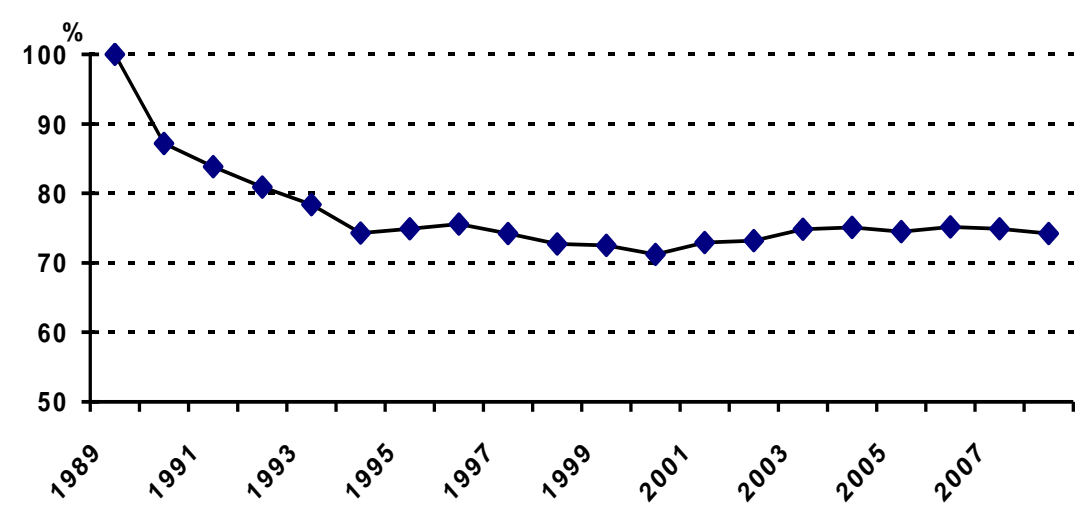


Figure 2: Number of Studies Published Yearly (2009 through August only)

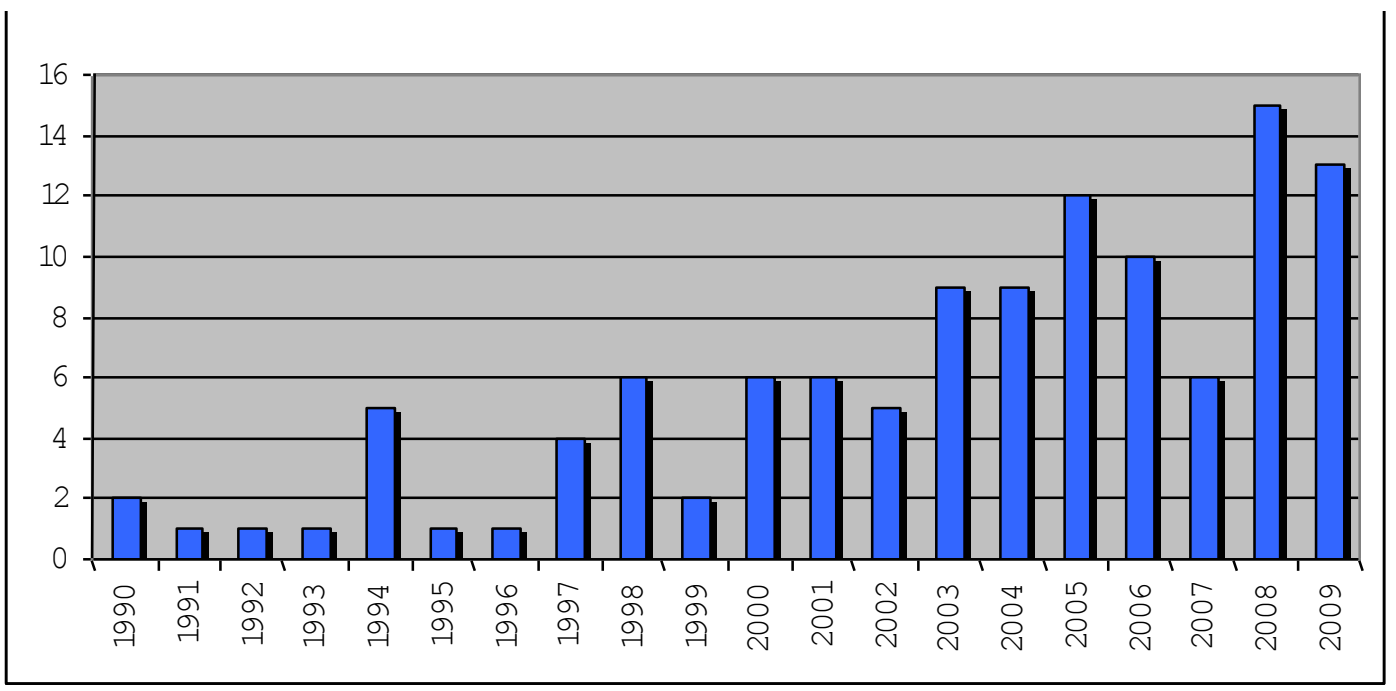

